\title{
The Influence of Capital Structure on Corporate Financial Performance Moderated by GDP: Analysis on the Food and Beverage Sub-Sector Listed on the IDX in 2013-2019
}

\author{
Khirstina Curry ${ }^{1}$, Imam Zul Fikri ${ }^{2}$ \\ $\left\{\right.$ k_curry@trisakti.ac.id ${ }^{1}$, imam.zulfikri@trisakti.ac.id ${ }^{2}$ \} \\ Applied Bachelor (D-IV) of Finance, Faculty of Economics and Business Universitas \\ Trisakti ${ }^{1}$, Applied Bachelor (D-IV) of Finance, Faculty of Economics and Business \\ Universitas Trisakti ${ }^{2}$
}

\begin{abstract}
Financial performance can be used to measure the success of a company. In this study, Gross Domestic Product (GDP) moderated the capital structure and financial performance. Higher GDP determines the appropriate composition of capital structure and improves the company's financial performance. This research used the panel data regression method. Results indicated that the factors influencing financial performance are Loan to Deposit Ratio (LDR), GDP moderated Domestic Product (GDP), GDP moderated Debt to Equity (GDER), and GDP moderated Loan to Deposit Ratio (GLDR). The financial performance of the company is influenced by the moderation of DER and LDR by GDP. In other words, a fairly strong influence is shown by economic conditions on the determination of the capital structure and also the improvement of the company's finances
\end{abstract}

Keywords: Capital Structure; debt; GDP

\section{Introduction}

Rapid economic developments have increased competition in the business sector. The condition encourages managers to play an important role in operations, marketing, and establishing strategies. Therefore, the company can survive the competition and achieve maximum profit. Financial managers control capital structure decisions to ensure sustainable company operations. Before choosing alternative funding, it is necessary to consider how the company can create a profitable combination between internal capital and external capital. In other words, it is necessary to consider how the company may create an optimal capital structure.

The optimal capital structure is to minimize the average cost of capital and maximize firm value. The company's performance and value are influenced by the optimal capital structure. Good company performance increase share prices in the capital market and increase shareholders' benefit. Capital structure decisions greatly determine the company's operation 
and risk. The high amount of debt may hinder the company's development. In turn, the shareholders may be reluctant to invest.

A company may decide to use internal or external capital. Increasing capital must increase the profit of company owners and shareholders. Investment, funding, and dividend policies determine the wealth of company owners and shareholders. The financial decisions that related to the composition of debt, preferred stock and common stock, it is called the capital structure. In regards to funding decisions, companies need to determine the capital structure. Thus, the company managers need to raise funds from outside or within the company efficiently, it is because minimizing the cost of capital is needed in funding decisions.

Indonesia has suffered from the Covid-19 pandemic since the end of 2019. Covid-19 pandemic declined community purchasing power and reduced the contribution of household consumption to Gross Domestic Product (GDP) by $2.07 \%$ in 2020 . Household consumption is one of the largest contributors to GDP, equivalent to $57 \%$. The contribution of the food and beverage industry to GDP is $23.8 \%$ (investasi.kontan.co.id).

The consumer goods sector index is the highest index with the least correction. It is in accordance with statistical data from the index of the consumer goods sector on the IDX, it is only corrected $12.01 \%$. The correction was lower than the IDX Composite (Indeks Harga Saham Gabungan - IHSG). The IDX Composite obtained 23.13\% correction since the beginning of the year or year-to-date (YTD) (investasi.kontan.co.id).

The weakening consumer goods index was not as severe as other sectoral indices, such as property and real estate $(32.84 \%)$ and the various industry sector index by $31.81 \%$. The consumption goods sector index was influenced by several food and beverage producers undergoing positive growth. PT Mayora Indah Tbk (MYOR) is recorded a positive return of $15.61 \%$. Then, PT Akasha Wira International Tbk (ADES), ia as a bottled water producer, it is recorded $6.7 \%$ gain since the beginning of the year (investasi.kontan.co.id).

The most prominent Indonesian food and beverages producers, PT Indofood Sukses Makmur Tbk (INDF) and PT Indofood CBP Sukses Makmur Tbk (ICBP), received correction since the beginning of the year. However, the correction of the Salim group was below the sectoral and IDX Composite, which reduced by $10.09 \%$ and $9.42 \%$ respectively since the beginning of the year (investasi.kontan.co.id).

A financially healthy company is indicated by a Debt to Equity Ratio (DER) below 1 or $100 \%$. The debt/liabilities that are smaller than all company assets, it indicates that their DER is low. So, when an unwanted event occurs (for example: bankruptcy), the company can pay off all its debts or obligations.

On the other hand, higher DER increases the total debt or liability composition compared to the total net capital. High DER creates a significant burden on the company. The increasing burden of liabilities to parties outside of the company shows that the company's source of capital is highly dependent on outsiders. Lack of debt management will negatively influence the company's financial health condition. The larger the company, the greater the ownership of assets. The amount of assets is an indication of the company's guarantee to fulfill its obligations.

Based on the background of the research, this research analyzed the effect of capital structure proxied by Debt to Equity Ratio (DER), Company Size (SIZE), Tangibility (TANG), and Loan to Deposit Ratio (LDR) on financial performance. Furthermore, financial performance is proxied by Return on Equity (ROE) and moderated by GDP. In addition, GDP shows how external factors affect the company's financial performance. 
the contribution of knowledge about the role of capital structure on company performance by moderating GDP is the contribution that to be achieved by this research. so the aim of this research are:

1. analyze Debt to Equity Ratio (DER) in its influence on Return On Equity (ROE).

2. analyze Loan to Deposit Ratio (LDR) in its influence on Return On Equity (ROE).

3. analyze company size (SIZE) related to its effect on Return On Equity (ROE).

4. analyze tangibility (TANG) related to its effect on Return On Equity (ROE).

5. analyze the Debt to Equity Ratio (DER) related to its effect on Return On Equity (ROE) which has been moderated by Gross Domestic Product (GDP).

6. analyze the Loan to Deposit Ratio (LDR) related to its effect on Return On Equity (ROE) moderated by Gross Domestic Product (GDP).

7. analyzed the firm size (SIZE) in its influence on Return On Equity (ROE) moderated by Gross Domestic Product (GDP).

8. analyze the effect of tangibility (TANG) on Return On Equity (ROE) moderated by Gross Domestic Product (GDP).

\section{Review of Related Literature}

Funding decisions related to capital structure or capital structure must be carried out appropriately by the company. The combination of debt and capital is a capital structure (Champion, 1999; Gosh et al., 2000; Tian and Zeitun, 2007; Hadlock and James, 2002; Abor, 2005; San and Heng, 2011; Chakraborty, 2010) that determines company decision and influence company value. Financial decision is a major decision due to optimal capital structure. The optimal capital structure represents the company's financing mix and maximizes the share price and company value. Capital structure refers to how a company finances its assets through a combination of capital and debt (Titman and Wessels, 1988; Brigham dan Ehrhardt, 2005).

There is no standard benchmark for the best capital structure. This assumption is explained as follows. If the company changes the composition of debt and equity by replacing some of its capital with debt, will there be a change in stock prices? Therefore, there are two important things to focus on, namely the composition of the capital structure and company value. Which, a good composition forms the best capital structure, while the influence of capital prices determines the value of the company. So, the optimization of both has the opportunity to reduce the debt ratio (Brigham \& Houston, 2006).

Taub (1975) mentions coefficient that measures the difference between the company's return consistently has a positive effect on the long-term interest rate. Increasing the company's return increases the possibility of debt issuance and indicates a positive impact on the company's desired debt to equity ratio (Mauer et al., 1994; Barclay et al., 1995). Fama and French (2002) state that companies capable of recording profits have a relatively smaller level of leverage. Furthermore, companies that have a lot of investments have smaller market leverage. Fama and French (1997) supported Meckling and Jensen (1976) and Myers (1977), which predicts a negative relationship between profitability and leverage.

Based on the Pecking Order Theory in Myers (1984), it is stated that if the probability level of a company is high, the debt level is low. It is because a large internal source of funds must be owned by them. In the Pecking Order Theory, it is known that there is no optimal structure of capital. It is because the order of preference (hierarchy) applies to the use of company funds. 
The funding order is explained by the Pecking Order Theory. And based on this theory, internal funding will be used first, then debt and followed by the issuance of shares which is the last option (Smart, Megginson, and Gitman, 2004). However, a contradictory thought occurs when actually an increase in net income can be increased by using debt. Companies that use debt to obtain tax savings because taxes are calculated from operating profit after deducting interest on the debt. Therefore, the value of the company will increase. High levels of debt can reduce agency problems between managers and shareholders. Higher debt can increase firm value by encouraging managers to act in the interests of external equity. In addition, higher debt decreases investment problems, especially in firms with excess cash (Jensen, 1986).

However, the company will not use the debt scenario as the only alternative to funding. Increasing debt means increasing the company's financial risk. Capital structure policy is similar to the exchange between risk and return. Capital structure affects financial performance and financial risk (Nadeem et al., 2015). Financial risk refers to the company's inability to pay interest and principal installments in a state of financial distress. Brigham and Houston (2011) state that:

1. Using debt in larger amounts will increase the risk borne by shareholders. Therefore, higher risk tends to lower stock prices indirectly.

2. On the other hand, the expectation of a higher rate of return will increase stock prices. It is assumed that using more debt will generally increase the expected return on equity.

Therefore higher level of debt reduces company value. Companies must be able to determine the amount of debt to increase company value. However, if the amount of debt exceeds a certain limit, it will reduce company value. Therefore, between the structure of capital and the value of a company there is a relationship, as the Modigliani-Miller Theorem states that the structure of capital influences the value of the company.

These are some previous studies, which are related to the capital structure that has an influence on the company's financial performance. Mathewos Woldermariam Birru (2016) used Multiple Regression Analysis. The results showed that the significant positive effect was indicated by the Debt Ratio (DR) to Return on Assets (ROA). While a significant negative effect is shown by DER, Size, and Tangibility to ROA, besides that, a significant positive effect is also shown by DER to ROE. And LDR does not have effect on ROA and ROE.

Riska Mandasari and Mukaram (2018) used Linear Regression Analysis. This study shows that a significant positive effect is shown by capital structure on ROE, Sales Growth, and Price Earning Ratio (PER). Then as much as $6.6 \%$ significant positive effect is shown by the capital structure on financial performance. The research from Slamet Mudjijah, et al (2019) uses Multiple Linear Regression Analysis. And from this study, it was found that a significant positive effect was shown by financial performance and capital structure on firm value. Furthermore, the insignificant effect is shown by firm size on firm value. It is because firm size does not moderate the effect of capital structure on firm value.

Previous research related to the effect that occurs on the capital structure on the company's financial performance, this has underpinned the concept of this research, so the researcher wanted to examine the structure in its influence on GDP which serves as a moderator. This research showed how external conditions influence the company's financial performance. The research framework is presented in figure 1.

Research from Mathewos Woldermariam Birru (2016) on the impact of capital structure on the financial performance of commercial banks in Ethiopia. In this study, 8 sample banks were used, which came from commercial banks in Ethiopia from 2011 to 2015. And Multiple Regression Analysis is used as a method of data analysis in this study. Furthermore, based on 
this study, it was found, a significant positive effect was shown by the Debt Ratio (DR) on ROA and RO, ROE was positively significantly influenced by DER. On the other hand, Size and Tangibility have a significant negative effect on ROE. And the last, the insignificant effect is shown by LDR to ROE. Therefore, the following hypotheses were formulated:

1. The effect is shown by the Debt to Equity Ratio (DER) on Return on Equity

2. The effect is shown by Loan to Deposit Ratio (LDR) on Return on Equity (ROE)

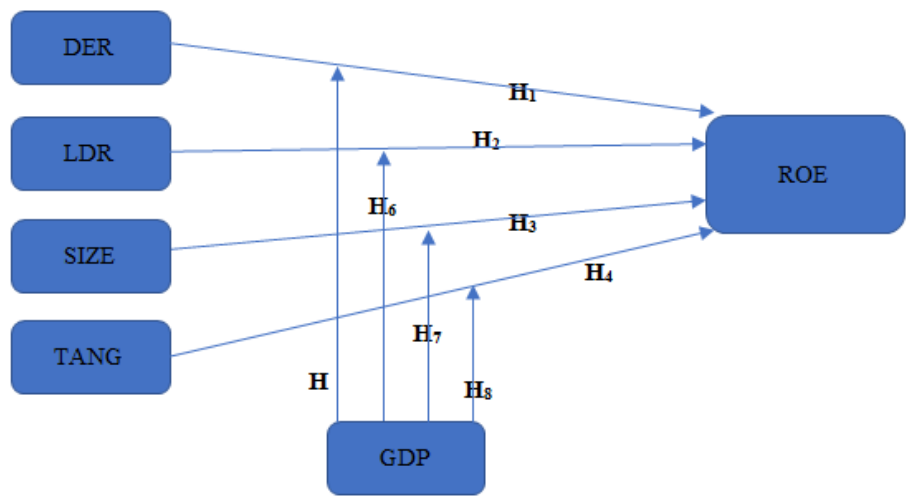

Fig 1. Conceptual Framework

Didy Handoko's (2016) research determined the dominant influence of company characteristic variables such as company size, profitability, growth opportunities, liquidity, and tangibility on capital structure. Furthermore, the research determined the influence of the capital structure on the company's value. Thus, predictions of changes in leverage are different between insurance companies on the Indonesia Stock Exchange, a researcher must determine which trade-off theory or Pecking Order Theory they use. The researcher used secondary data from 10 insurance companies (non-life insurance) during 2008-2013. The analytical method was the Panel Data Method. The research showed that the characteristics of the dominant variables influencing the company's capital structure are company size, growth opportunities. In addition, the variables had a positive influence on the negative variable (liquidity). The positive influence is shown by the capital structure and the value of the tradeoff theory on general insurance companies, which are on the IDX. Therefore the following hypotheses were formulated:

1. Return on Equity is influenced by Company Size (SIZE)

2. The influence of Tangibility (TANG) shown on Return on Equity (ROE)

The study by Muchiri et al. (2016) revealed that Short Term Debt (STF), Long Term Debt (LTD), retained earnings, and external equity has a significant negative influence on ROA and no significant influence on ROE. The moderating variable has a significant influence on ROA and ROE. Based on the descriptions above, the following hypotheses were formulated:

1. The Debt to Equity Ratio is moderated by Gross Domestic Product (GDP) and Return On Equity (ROE), but it is also influenced by GDP

2. GDP moderates LDR and influences Return On Equity (ROE)

3. GDP moderated Company Size (SIZE) influences Return On Equity (ROE)

4. GDP moderated Tangibility (TANG) influences Return On Equity (ROE) 


\section{Research Method}

The effect of capital structure on the company's financial performance which is moderated by GDP, it is what will be analyzed in this study. The food and beverage sub-sectors listed on the IDX from 2013 to 2019 are what is analyzed in this study. This research was quantitative. Quantitative research involves statistical data collection. Calculations and interpretations are presented in the form of graphs, diagrams, tables, and hypothesis testing. The scope of this research was companies listed on the Indonesia Stock Exchange (IDX) from 2013 to 2019.

The moderating factor in this study was taken from the analysis of the effect of capital structure on financial performance in companies with GDP, which used the Panel Data model equation. Due to the number of time series and the size of the company it is possible to analyze using this Panel Data Model. The equation was as follows:

$$
\begin{array}{r}
\mathrm{ROE}_{\mathrm{it}}=\alpha_{0}+\beta_{0} \mathrm{DER}_{\mathrm{it}}+\beta_{1} \mathrm{LDR}_{\mathrm{it}}+\beta_{2} \mathrm{Size}_{\mathrm{it}}+\beta_{3} \operatorname{Tang}_{\mathrm{it}}+\beta_{4} \mathrm{GDP}_{\mathrm{it}}+ \\
\beta_{5} \mathrm{DER}_{\mathrm{it}} * \mathrm{GDP}_{\mathrm{it}}+\beta_{6} \mathrm{LDR}_{\mathrm{it}} * \mathrm{GDP}_{\mathrm{it}}+\beta_{7} \mathrm{SIZE}_{\mathrm{it}} * \mathrm{GDP}_{\mathrm{it}}+\beta_{8} \mathrm{TANG}_{\mathrm{it}} * \mathrm{GDP}_{\mathrm{it}}
\end{array}
$$

The population of this study came from manufacturing companies that listed on the Indonesia Stock Exchange. Furthermore, related to the sample, this is processed by the purposive sampling method. It is called so because the sample was taken with certain considerations.

The sampling technique using certain considerations, based on the statement Sugiyono (2001), it is called purposive sampling. And in this selection, it is based on the level of closeness to the characteristics of the pre-existing population. So, it can be concluded that the sample unit will be adjusted to certain criteria related to the research objectives. The criteria for sample selection were as follows:

1. A food and beverage company possessing Initial Public Offering (IPO) in 2012

2. Positive net income during $2013-2019$

3. Have all the information needed during the research period

Table 1. Variables, Operational Definitions (Measurements), and References

\begin{tabular}{cccc}
\hline $\begin{array}{c}\text { Variable } \\
\text { Type }\end{array}$ & $\begin{array}{c}\text { Variable } \\
\text { Name }\end{array}$ & Operational Definition & Measurement \\
\hline \multirow{2}{*}{ Dependent } & ROE & $R O E=\frac{\text { Net Profit After Tax }}{\text { Total Equity }}$ & percent \\
Independent & DER & $D E R=\frac{\text { Total Liabilities }}{\text { Total Assets } 100 \%}$ & percent \\
& SIZE & SIZE $=$ Ln Total Assets & Index \\
& TANG & Tang $=\frac{\text { Fixed Assets }}{\text { Total Assets } 100 \%}$ & percent \\
& LDR & LDR $=\frac{\text { Non }- \text { Current Liabilities }}{\text { Total Assets }}$ & percent \\
& GDP & Economic Growth $=\frac{G D P_{t}-G D P_{t-1}}{G D P_{t-1}}$ X $100 \%$ & percent \\
\hline
\end{tabular}

Researchers used Panel Data Regression, related to the analysis related to the effect of capital structure on financial performance in manufacturing companies. with a time period between 2013 and 2019. Panel Data Regression accommodates multiple time series and multiple companies. In addition, this method can show different behavior of each company, especially the influence of capital structure on financial performance. 
Panel data has several models to estimate model parameters, namely (1) Common Effect Model (CEM), (2) Fixed Effect Model (FEM), and (3) Random Effect Model (REM). There are three tests that can be used to select panel data estimation techniques (Widarjono, 2007). the first, the F-statistics test, it is used to choose between CEM or FEM. Second, the Hausman test chooses between FEM or REM. Third, the Lagrange Multiplier (LM) test choose between CEM or REM.

According to Nachrowi (2006), FEM or REM usage need to consider the purpose of the analysis. Furthermore, the method needs to be considered if the data used, it is as the basis of the model, that can only be processed with one method, it is because, it is related to mathematical technical problems, which are the basis for the calculations. In Eviews software, if the number of individuals exceeds the coefficient, including intercepts, then REM can only be used. In addition, some econometricians argue that FEM can be used when the amount of time $(t)$ it has greater than the number of individuals (i) based on panel data. Furthermore, it is recommended to use REM when the amount of time $(\mathrm{t})$ is less than the number of individuals.

\section{Finding and Discussion}

There are 30 food and beverage companies listed on the Indonesia Stock Exchange (IDX) in 2020. The researcher used purposive sampling to select fourteen companies that meet the criteria. Table 2 shows the selected companies.

\begin{tabular}{cclc}
\multicolumn{5}{c}{ Table 2. List of Sample Companies } \\
\hline No. & Company Code & \multicolumn{1}{c}{ Company Name } & IPO \\
\hline 1 & ADES & Akasha Wira International Tbk & $13 / 06 / 94$ \\
2 & BUDI & Budi Starch \& Sweetener Tbk & $08 / 05 / 95$ \\
3 & CEKA & Wilmar Cahaya Indonesia Tbk & $09 / 07 / 96$ \\
4 & DLTA & Delta Djakarta Tbk & $12 / 02 / 84$ \\
5 & ICBP & Indofood CBP Sukses Makmur Tbk & $07 / 10 / 10$ \\
6 & INDF & Indofood Sukses Makmur Tbk & $14 / 07 / 94$ \\
7 & MLBI & Multi Bintang Indonesia Tbk & $17 / 01 / 94$ \\
8 & MYOR & Mayora Indah Tbk & $04 / 07 / 90$ \\
9 & ROTI & Nippon Indosari Corpindo Tbk & $28 / 06 / 10$ \\
10 & SKBM & Sekar Bumi Tbk & $05 / 01 / 93$ \\
11 & SKLT & Sekar Laut Tbk & $08 / 09 / 93$ \\
12 & STTP & Siantar Top Tbk & $16 / 12 / 96$ \\
13 & TBLA & Tunas Baru Lampung Tbk & $14 / 02 / 00$ \\
14 & ULTJ & Ultra Jaya Milk Industry \& Trading Company Tbk & $02 / 07 / 90$ \\
\hline \multicolumn{5}{c}{ Source: IDX (processed) }
\end{tabular}

Financial performance, capital structure, and asset structure are presented in Table 3. Table 3 describes the conditions of the average value (mean), minimum value, maximum value, and the standard deviation of each variable from the sample companies.

Table 3. Descriptive Statistics 
Date: 07/30/21 Time: 06:19 Sample: 20132019

\begin{tabular}{lccccc}
\hline \hline & ROE & DER & LDR & SIZE & TANG \\
\hline \hline Mean & 21.22277 & 59.68706 & 0.163714 & 15.06406 & 42.88838 \\
Median & 15.80000 & 27.45500 & 0.156636 & 14.75939 & 45.57065 \\
Maximum & 142.0000 & 303.0000 & 0.505245 & 18.38545 & 78.39780 \\
Minimum & 0.000699 & 0.450000 & 0.013998 & 12.61815 & 0.144950 \\
Std. Dev. & 26.55224 & 65.04218 & 0.117724 & 1.461866 & 17.73742 \\
Skewness & 2.907063 & 0.915846 & 0.737213 & 0.699637 & -0.556606 \\
Kurtosis & 11.43732 & 3.378676 & 2.919871 & 2.710159 & 2.597061 \\
& \multicolumn{5}{c}{ Source: IDX (processed) } \\
\end{tabular}

The average ROE of fourteen food and beverage companies was $21.22 \%$. Therefore, the companies can generate a net profit of $21.22 \%$ of their equity on average. Two companies have above-average ROE values, namely DLTA and MLBI. The remaining 12 companies had below-average ROE values. There was a relatively large gap between one company and another. In addition, The standard deviation value was higher than the average. A minimum ROE of $0.0007 \%$ was generated by SKBM companies in 2019, and a maximum ROE of 142 $\%$ was generated by MLBI companies in 2014.

The average DER of fourteen food and beverage companies was $59.69 \%$. Therefore, the companies' ability to fulfill equity obligations was $56.69 \%$. Five companies obtained aboveaverage DER values, namely BUDI, MLBI, MYOR, SKLT, and TBLA. The remaining nine companies obtained below-average DER values. Therefore, the research sample has a fairly good ability to fulfill equity obligations. ADES generated a minimum DER of $0.450 \%$ in 2019, and MLBI generated a maximum DER of $303 \%$ in 2014.

The ability of a company to meet long-term obligations, especially those related to the use of assets, is called LDR. The average LDR value was $0.16 \%$. Seven companies obtained above-average LDR values, namely BUDI, INDF, MYOR, ROTI, SKLT, STTP, and TBLA. ADES, CEKA, DLTA, ICBP, MLBI, SKBM, and ULTJ obtained below-average LDR values. ICBP had the lowest LDR (minimum) in 2019. TBLA had the highest (maximum) LDR in 2018. In other words, TBLA had the best performance in 2018.

ICBP, INDF, MYOR, TBLA, and ULTJ had above-average SIZE values. ADES, BUDI, CEKA, DLTA, MLBI, ROTI, SKBM, SKLT, and STTP had below-average SIZE values. SKLT had the lowest total assets owned in 2013. INDF had the highest total asset in 2018. SKBM had the lowest TANG in 2019. ROTI had the highest TANG in 2014. The average TANG was $42.89 \%$ from 2013 to 2015 . The ratio between fixed assets and total assets was 42.89 , indicating that fixed assets owned were $42.89 \%$ of the total assets owned. ADES, BUDI, ICBP, INDF, MLBI, ROTI, SKLT, and STTP had above average TANG values. The other five companies had below-average TANG values.

FEM was the selected model from the panel data regression. The researchers performed Chow Test after the CEM and FEM regressions to select the appropriate method. Chow test showed $\alpha$ value of $5 \%$. The probability value of the chi-square cross-section is 0.0000 , which is below $\alpha$. Therefore, FEM is more appropriate than CEM.

Hausman test determined whether REM or FEM was appropriate. The Hausman test result showed a random cross-section probability value of 0.0471 , below $\alpha$ value $(5 \%)$. Therefore, the FEM model was selected. The ability of DER, SIZE, TANG, LDR, and GDP in explaining the variation of influence on ROE is $91.09 \%(0.9109)$. The remaining $8.91 \%$ is influenced by other factors.

DER, SIZE, TANG, LDR, and GDP simultaneously influence ROE. The probability value of the F-statistic at 0.000000 , which is below the $\alpha$ value. The t-count probability of LDR was 
0.0003, which is smaller than $\alpha$ value. Therefore LDR influenced ROE. The t-count probability of SIZE was 0.0007 , which is smaller than $\alpha$ value. Therefore SIZE influenced ROE.

The t-count probability of TANG was 0.0183 , which is smaller than $\alpha$ value. Therefore, TANG influenced ROE. The t-count probability of GDP was 0.0129 , which is smaller than $\alpha$ value. The t-count probability of GDER, GLDR, GSIZE, and GTANG were 0.0002, 0.0004, 0.0038 , and 0.0164 , respectively. Each variable was smaller than $\alpha$ value. Therefore, the four variables partially influenced ROE. The t-statistics probability of DER was 0.1362 , which is smaller than $\alpha$ value. Therefore, DER did not influence ROE. After the researchers selected the model, assessed the model fit test, and conducted a hypothesis testing, the following equation was formulated:

$$
\begin{aligned}
& \mathrm{ROE}_{\mathrm{it}}=332,47-0,02 \mathrm{DER}_{\mathrm{it}}+773,68 \mathrm{LDR}_{\mathrm{it}}-22,95 \mathrm{Size}_{\mathrm{it}}-2,45 \mathrm{Tang}_{\mathrm{it}}-87,62 \mathrm{GDP}_{\mathrm{it}}+ \\
& 3,91 \mathrm{DER}_{\mathrm{it}} * \mathrm{GDP}_{\mathrm{it}}-254,27 \mathrm{LDR}_{\mathrm{it}}{ }^{*} \mathrm{GDP}_{\mathrm{it}}+6,49 \mathrm{SIZE}_{\mathrm{it}} \mathrm{GDP}_{\mathrm{it}}+0,84 \mathrm{TANG}_{\mathrm{it}} \mathrm{GDP}_{\mathrm{it}}
\end{aligned}
$$

Based on the equation, if DER, LDR, Size and Tang, GDP, and GDER, GLDR, GSIZE, GTAND are considered constant or equal to zero, the ROE is $332.47 \%$. Current liabilities are a form of short-term obligation. Generally, current liabilities are company debts related to the company's operational activities and are short-term. For example, debts to suppliers, paying salaries, or debts for purchasing production equipment.

Short-term liabilities in this study are proxied by DER. Fluctuating DER did not influence ROE. Therefore, short-term equity obligations did not influence the company's financial performance. Samples from food and beverage companies, proven to be able to fulfill more than $50 \%$ of their obligations. This indicates that most sample companies can meet their shortterm obligations well and not affect their financial performance.

This research was in line with Jufrizen and Sari (2019) and Alpi (2018) that DER did not significantly influence financial performance (ROA). However, this research differed from Birru (2016) and Mandasari (2018), which stated that DER influenced ROE. LDR shows the company's ability to meet its long-term obligations. Based on the research result, LDR had a positive influence on ROE. If LDR increases by $1 \%$, the ROE will increase by $773.67 \%$. Therefore, when a company's capability to fulfill long-term obligations increases, its financial performance will increase up to 773 times.

SIZE had a negative influence on ROE. If SIZE increases by one time, ROE will decrease by $22.95 \%$. Therefore, increasing assets will increase the burden and reduce income. Increased expenses will reduce profits and decrease company performance. Increasing TANG will decrease ROE. If TANG increases by $1 \%$, then ROE will decrease by $2.45 \%$. The size of the fixed assets will affect the size of the burden incurred. Fluctuating expenses will affect income and profit.

Pseudo moderating variable (Quasi Moderator) is often abbreviated as GDP. while the variable that moderates the relationship between the independent variable and the dependent variable is called a quasi moderator. And it includes the independent variable. The regression results showed that GDP and DER, LDR, SIZE, and TANG moderated by GDP (GDER, GLDR, GSIZE, and GTANG) influenced the company's financial performance (ROE).

GDP moderated DER, LDR, SIZE, and TANG on the company's financial performance. GDP strengthened the effect of capital structure and asset structure on the company's financial performance (ROE). Therefore, macroeconomic conditions influence a company's financial performance. 
If GDP moderated DER increased by $1 \%$, then ROE increased by $3.9 \%$. The company's ability to meet short-term obligations will increase when moderated by GDP. Therefore, macroeconomic conditions influence the company's internal condition and financial performance. Negative influence indicated by the LDR on financial performance that has been GDP moderated. If GLDR increased by one time, then ROE decreased by $254.27 \%$. Increasing GDP indicates improving economic conditions. Increasing GDP will improve the company's ability and encourages the fulfillment of long-term obligations. A company's ability to meet long-term obligations will reduce revenue due to the burden incurred.

If GDP moderated SIZE increased by one time, then ROE increased by $6.49 \%$. When the economy improves, the company will invest in purchasing assets. Doing so will increase the company's income and improve financial performance (ROE). If GDP moderated TANG increased by one, then ROE increased by 0.8 . Improving the economy encourages TANG growth and company performance.

\section{Conclusion and Suggestion}

The research result showed that GDP moderated the effect of capital structure on financial performance. Therefore, the following conclusions were drawn:

1. The company's financial performance is not affected by DER.

2. Financial performance is positively influenced by LDR.

3. negative influence shown SIZE on financial performance.

4. negative influence shown TANG on financial performance.

5. The effect shown DER, LDR, SIZE, and TANG on financial performance have been GDP moderated.

6. Positive influence shown DER on financial performance that has been GDP moderated

7. negative influence indicated by the LDR on financial performance that has been GDP moderated

8. Positive influence shown SIZE on financial performance that has been GDP moderated

9. Positive influence shown TANG on financial performance that has been GDP moderated.

Companies are advised to be careful in performing financial planning and budget utilization. A very large influence is shown by the combination of the best capital structure on the financial performance of a company. Companies must also pay attention to the company's external conditions because macroeconomic conditions can affect the company's financial performance through the application of capital structure and asset structure. There are several suggestions to improve the company's financial performance:

1. Improve the ability to fulfill long-term obligations.

2. Reduce the rate of asset increase.

3. Anticipate changes in macroeconomic conditions.

\section{References}

[1] Abor, J.: The effect of capital structure on profitability: an empirical analysis of listed firms in Ghana. Journal of Risk Finance, 6, pp. 438-447 (2005)

[2] Achmad A. P.: Faktor-faktor yang Mempengaruhi Struktur Modal pada Perusahaan Manufaktur yang Terdaftar di BEI, Jurnal Ekonomi Manajemen, pp. 1 - 2 
[3] Admassu, N. A.: “The Impact of Capital Structure Choice on Firms' Financial Performance: Evidence From Manufacturing PLCs in Tigrai”. Journal of Poverty, Investment and Development (2016)

[4] Alpi, M.F.: Pengaruh Debt to Equity Ratio, Inventory Turn Over, Dan Current Ratio Terhadap Return On Equity Pada Perusahaan Sektor Farmasi Yang Terdaftar Di Bursa Efek Indonesia, Prosiding: The National Conferences Management and Business (NCMAB) 2018, ISSN: 2621 - 1572, pp. 158-175 (2018)

[5] Birru, M. W..: The Impact of Capital Structure on Financial Performance of Commercial Banks in Ethiopia. Global Journal of Management and Business Research: Finance (2016)

[6] Chadha, Saurabh, and Anil KS: Determinant of Capital Structure: An Empirical Evaluation From India. Journal of Advanced in Management Research Emerald Group Publishing Limited (2015)

[7] Deesomsak, R., Paudyal, K., \& Pescetto, G.: The determinants of capital structure: evidence from the Asia Pacific region. Journal of multinational financial management, 14(4), pp.387-405 (2004)

[8] Farah M. and Dian N. S.: Faktor-faktor yang Mempengaruhi Struktur Modal pada Industri Barang Konsumsi, Jurnal Manajemen, pp. 37

[9] https://investasi.kontan.co.id/news/industri-mamin-masih-akan-tertekan-simak-sahamsaham-rekomendasi-analis accessed on $30^{\text {th }}$ July 2021.

[10] https://investasi.kontan.co.id/news/emiten-makanan-minuman-dinilai-aman-darisentimen-resesi-dan-psbb accessed on 30th July 2021.

[11] https://id.investing.com/analysis/debt-to-equity-ratio-dalam-laporan-keuanganperusahaan-200210336 accessed on $30^{\text {th }}$ July 2021.

[12] Jufrizen and Sari, M.: Pengaruh Current Ratio, Debt To Equity Ratio Dan Firm Size Terhadap Return On Equity. Jurnal Riset Akuntansi Aksioma. Vol 18. No. 1, June (2019).

[13] Kifle, A.: Capital Structure and Financial Performance:Evidence from Ethiopian cement Companies. Addis Ababa University (2016)

[14] Mandasari, Riska and Mukaram: Analisis Pengaruh Struktur Modal Terhadap Kinerja Keuangan (Studi Pada Perusahaan Properti dan Real estate yang Terdaftar di Bursa Efek Indonesia periode 2012-2016), Industrial Research Workshop and National Seminar Vol 9 (2018). Prosiding Industrial Research Workshop and National Seminar, DOI: https://doi.org/10.35313/irwns.v9i0

[15] Modigliani, F. \& Miller, H.: The Cost of Capital, Corporate Finance and The Theory of Investment. The American Economic Review, volume XLVIII, June 1958 Number Three. 11 (1958).

[16] Modigliani, F. \& Miller, H.: Corporate Income Taxes and Cost of Capital: A correction. TheAmerican Review, Vol. 53, No. 3 (June 1963), pp 433 - 443 (1963)

[17] Modigliani, F. \& Miller, H.: Debt and Taxes. The Journal of Finance, Vol. 32, No.2, Papers and Proceedings of the Thirty-fifth Annual Meeting of the American Finance Association, Atlantic City, New Jersey, September 16-18, 1976 , pp. 261 - 275 (1977)

[18] Muchiri, Mwangi J., Willy M. M., Patrick M N.: . "Relationship Between Financial Structure and Financial Performance of Firms Listed at East Africa Securities Exchanges". Journal of Emerging Issue in Economics, Finance and Banking (JEIEFB): An Online International Research Journal (ISSN: 2306-367X), Vol: 5 Issue 1 (2016) 
[19] Nimalathasan, B., \& Brabete, V.: Capital Structure and its impact on Profitability: A study of Listed Manufacturing Companies in Sri Lanka. Revista Tinerilor Economist (The Young Economists Journal), volume 1, Issue 15, November (2010)

[20] Nwaolisa, Echekoba F., and Ananwude A. C.: The Effect of Financial Structure on the Performance of Nigeria Consumer Goods Firms. Journal of Scientific Research \& Reports 10(4): 1-15; Article no.JSRR.24569 ISSN: 2320-0227 (2016) 